\title{
Impact of truck art, as popular culture on Pakistani society
}

\author{
Samina Zia Sheikh ${ }^{*}$ \\ College of Art and Design, University of the Punjab, Lahore, Pakistan \\ Received 03 Aug 2018, Accepted 05 Oct 2018, Available online 06 Oct 2018, Vol.6 (Sept/Oct 2018 issue)
}

\begin{abstract}
Several theories directly deal with popular culture rather mass media, though; they both are closely knitted now. Popular culture in Pakistan is well portrayed through moving canvases on roads in form of trucks that also play equal role as mobile billboards. Meanings that from popular culture are taken are well interpreted as available artefacts, films, cloths, records, Television programs, as well as modes of transport. Classification of unlimited that man experiences, sees or takes information from does not have a strict or exclusive definition. Beliefs, practices, traditions, taboos, kinetics, different objects are all essentials of every culture. Truck art as popular culture in Pakistan brings forth an assortment of experiences, expressions, feelings, perceptions, ideologies, faiths through harmonized amalgamation of images, writings as well as three dimensional embellishments and leaves enormous impact on community. Focus of this study is to interpret frequently seen metaphors that have allegoric, emblematic, historic or contemporary significance the way they are communicated through visuals. This study highlights an extensive introduction of an extraordinary art which is an outstanding amalgamation of art and crafts in form of ornamentation and embellishment of heavy vehicles. It also covers the styles and materials used in ornamentation and philosophy that is adopted in various patent schemes and objects. Truck art, as popular culture is an attempt to examine and unlock deeper significance of metaphors that are accepted by people in dissimilar ways. Analysis of frequently conveyed messages through skilfully employed epigraphy and poetic interpretations leave ironic effect and make it more fun than its aesthetic value. Such interpretations enable one to become detective with most interesting analysis of cultural beliefs, taboos, traditions and values. Unquestionably truck art as popular culture plays an active role in communication and is a strong medium of expression.
\end{abstract}

Keywords: Trucks, Epigraphy, Metaphors, Craft works, Ornamentation, Popular culture.

\section{Introduction}

Disposition of art around us has in numerous styles, shapes and displays. The traditional cultural art around us is in multiple verities and it so happens that we sometimes do not take a reasonable notice of it. This research observes truck art as popular culture that has an impact on communities. Effort is to make people aware of this remarkable art which is present in our culture from many years but very few people are actually aware of it and it is treated as low art. One notion looks clear, nonetheless 'high' and 'low' both are yet read as adjective of divergent value we should not associate the high/low dissimilarity with a desire of peculiarity in between good or bad art. Even if high art unquestionably brings to intellect canonical works in an assortment of art forms and there is a great deal of high art-painting, poetry, and music that is bland of ordinary, inconsequential, and ornamental and so onwards. On the other hand it does

*Corresponding author's ORCID ID: : 0000-0001-5927-8830 DOI: https://doi.org/10.14741/ijmcr/v.6.5.10 not seem credible that all music is low art than readings and performance. ${ }^{[1]}$

Truck art which is considered low art within scholarly art communities is yet a strong source of communication within and around cultures. Art, very often is assessed on standard aesthetics, based on analysis of its status and function. Urbanization has also paved way for many other art forms known as popular art. Art is commonly produced for two classes, one, elite and the other known to popular art which is understandable by general viewers. Art in the beginning was focused to social issues though later subjects expanded and art was produced within cultures and subjects were centred to communities and their issues of daily life. Truck art has equivalent status it does not only represent communities with which it belongs, nonetheless, it offers an assortment of philosophies, narrative as well as metaphors. Although the art is around us from several decades we do not know such intricacies as such but the truck art is also one of such arts and it should be likewise regarded as other fine arts. Clues are found while investigations when made on 
intellectual ways for which we just need to look at this art form in a flexible way.

Most of the data for this research is based on direct observations as well as structured and non structured interviews from artists, artisans and craft persons. First section of the paper demonstrates knowledge of skilful crafts and how they are harmonized with other ornamentations such as metaphoric paintings, epigraphic messages and kinetic objects. Exciting explanations of artists and calligraphers from guilds that how do they interpret communicative metaphors of this art and further philosophies based on human experiences are very essence of this research paper. Emotional, philosophical, historic interpretations through truck art are a strong source of inspiration for onlookers in Pakistani societies and unquestionably truck art as popular culture is a strong source of communication.

\section{Diverse amalgamation of art and crafts in emblematic art of trucks}

Pakistan's colourful trucks and buses look like dazzling exotic flowers in an ever increasing black smoke and coughing traffic. These vehicles involve extraordinary and highly artistic craft works. Once you travel in Asia you frequently catch sight of these decorative trucks that are used for transportations of a variety of goods. This is amazing to observe that how elaborately these trucks are adorned with various decorative crafts and painted visuals. A range of truck made of various companies one can see on road such as Nissan, Hino, Mazda, as well as old Bedford that are locally called 'Rockets', are all overly decorative and capture the eye of viewers. Undoubtedly these trucks are emblematic art moving on wheels on dusty roads. They are not less than moving canvases with appealing imagery and adorned further with remarkable craftsmanship. Decoration of these trucks gives us clear idea of competition between owners of these vehicles in execution of outrageous and daring images, designs and ornamental patterns. These aesthetically adorned vehicles are pleasure for the eyes of observers.

Truck art represents a truck driver's journey that drives this vehicle for long hours. Body of these trucks is highly decorative but unfortunately much attention is not paid to maintenance of what under the bonnet is. Overloaded trucks meet bad fortunes and are seen frequently broken on roads. Countless trucks run on dusty road of cities and as well as in mountains and transport a range of goods to far places. Majority of trucks moving on G.T road might seem indistinguishable at first glance but trained eye of painter recognizes the exact areas of truck origin and $\bar{u} s t \bar{a} d^{[2]}$ or workshop from where it is embellished. There were times when truck drivers used to identify trucks fundamentally from the elements depicted on its sides and other embellishments that are involved in its adornment. Subjects including birds, animals, and imaginary landscapes, valleys with hills, lakes and forests are frequently depicted on these trucks with vibrant colours that capture the attention towards this art form. (Plate.1)

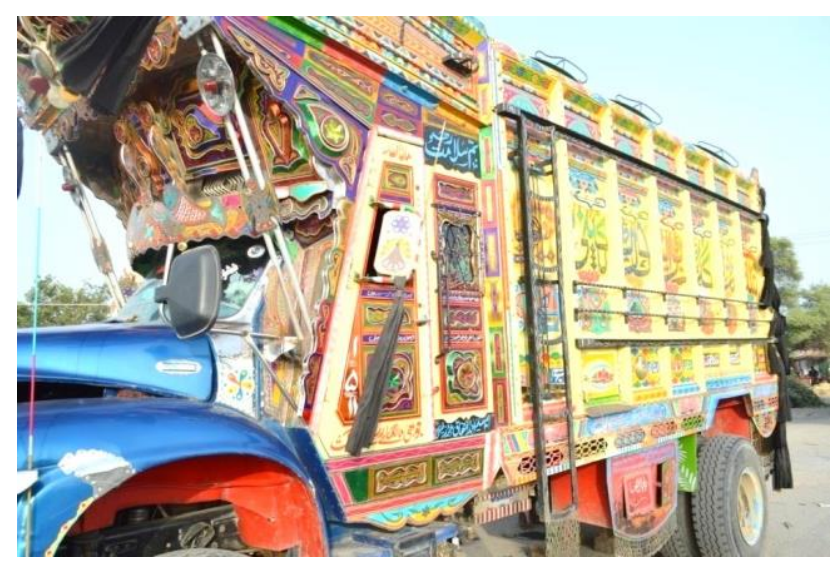

Plate.1 Highly ornate front and side of truck with dissimilar craft works.

Trucks embellished years back were mostly handmade that was the reason of such classification but many readymade decorative items that are imported from countries such as India, China, Japan and Taiwan have made it difficult to identify the workshops from where trucks are embellished due to the use of identical items of adornment. (Plate.2) Still there are possibilities to recognize the workshops in many cases and it is due to skilful craftsmanship that is applied in addition to these readymade items.

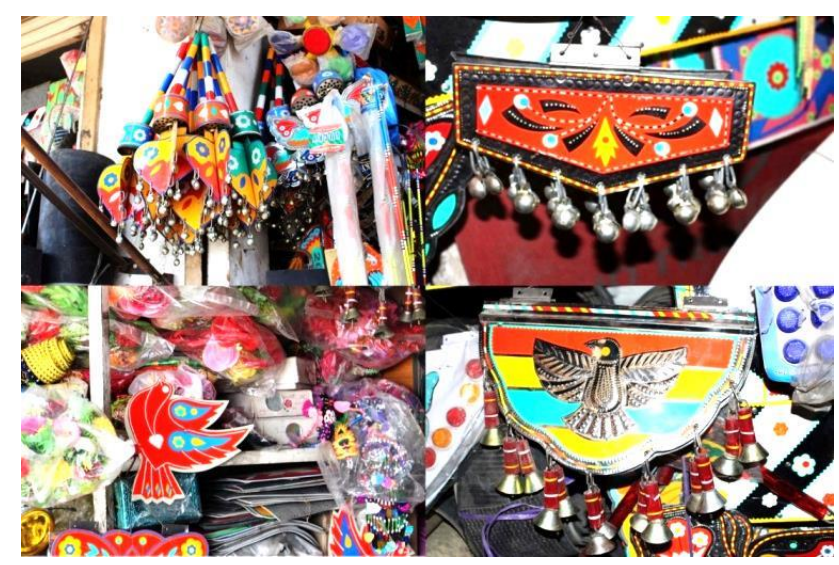

Plate.2 Readymade embellishments available in market.

Starting from Punjab, Rawalpindi, Hassan Abdal, Haripur, Gujranwala if adornment styles are analyzed on can see that plastic, acrylic and mirrors are used to ornate area above windshield that is known as $t \bar{a} j^{[3]}$. (Plate.3) Another astonishing craftsmanship is the light work that adds to overall effect of the truck, mainly done on the tāj, Lights on $t \bar{a} j$ that display the height of truck and lights on sides give the idea of truck's width. Back light is used to prevent from accidents and side lights show the length of vehicle. Some lights are used as means of communication with other drivers. 
An infinite variety of decoration in this section of trucks in applied in dissimilar ways. This variation is not only in designs that are opted for adorning tāj but also with structural design and materials selected for embellishments. Along with a verity of decorative materials woodwork is also involved in the decoration of $t \bar{a} j$ which is the highest point of vehicle and can be seen clearly from far distance. (Plate.4)

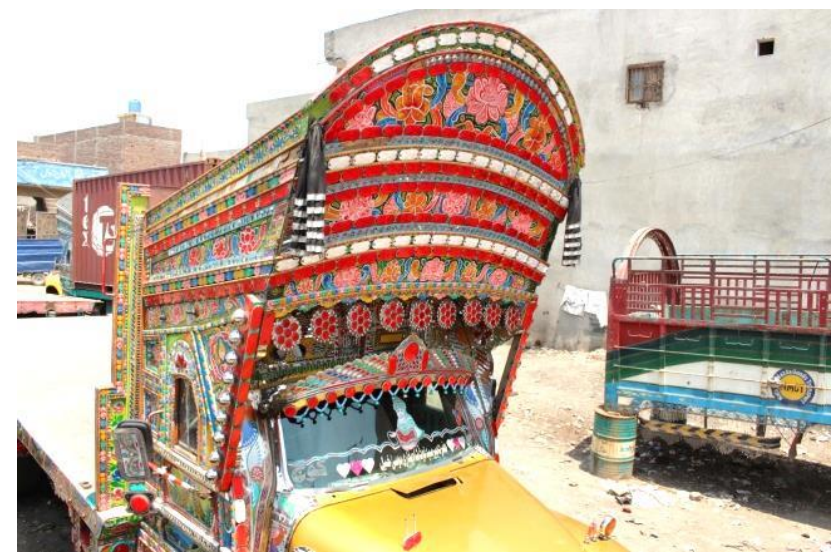

Plate.3 Tāj of truck adorned with plastic, acrylic mirror work and other readymade embellishments.

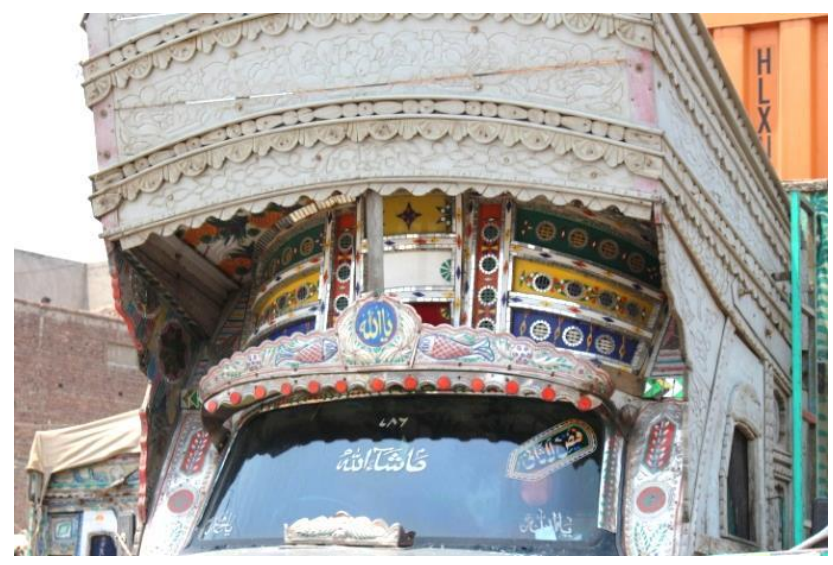

Plate.4 Tãj of truck decorated with woodwork.

Wood carving and inlay is frequently used in the front part and doors of trucks. Partal ${ }^{[4]}$ wood is used for these carvings. (Plate.5) Northern region and Swat are famous for the wooden carved doors and metal hammered work though use of acrylic is limited in their trucks. Peshawar style is a mixture of Swat and Rawalpindi styles and $t \bar{a} j$ is less ornate than in Punjabi trucks. Carved doors of wood are frequently seen in Swat trucks but orientation of images is far removed from other areas of Pakistan. These wooden doors are adorned with intricate carving of floral motifs as if these doors are entrance to heavens. All such decoration leaves a great impact to the psyche of the truckers who drive these heavy vehicles for long hours and develop a unique bonding with their vehicles. Balauch area of Pakistan covering Quetta, Dera Ghazi Khan, and Karachi have trend of mosaic, appliqué in intricate designs and in addition have 'cow catcher' bumpers in truck ornamentation. Karachi trucks' decor covers various styles of all above mentioned regions from where mostly the truck driver belongs.

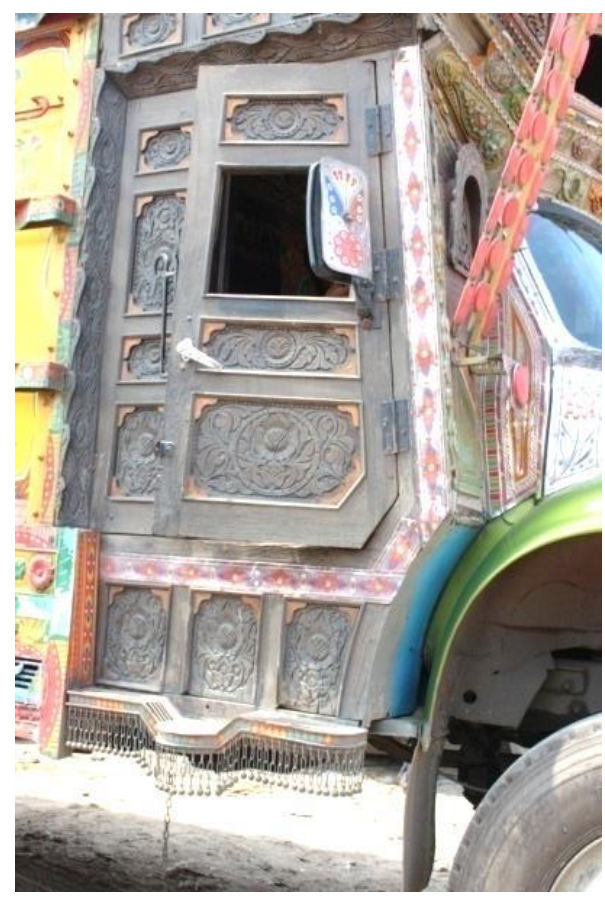

Plate. 5 wooden door of truck intricately decorated with floral carvings.

Truck driver spend a huge amount of money for the decoration of their vehicles. These decorations do not comprise of only painted images but structural designs as well. Additions made to the body of trucks are decorative as well as functional in both cases much attention is given to front and rear part of trucks. Intense decoration is applied to each and every part of additional structures to make them look stunning and delightful. (Plate.6) Structural additions are adorned in a harmonious way with the rest of the truck decoration where other ornamentations such as images and written messages are done.

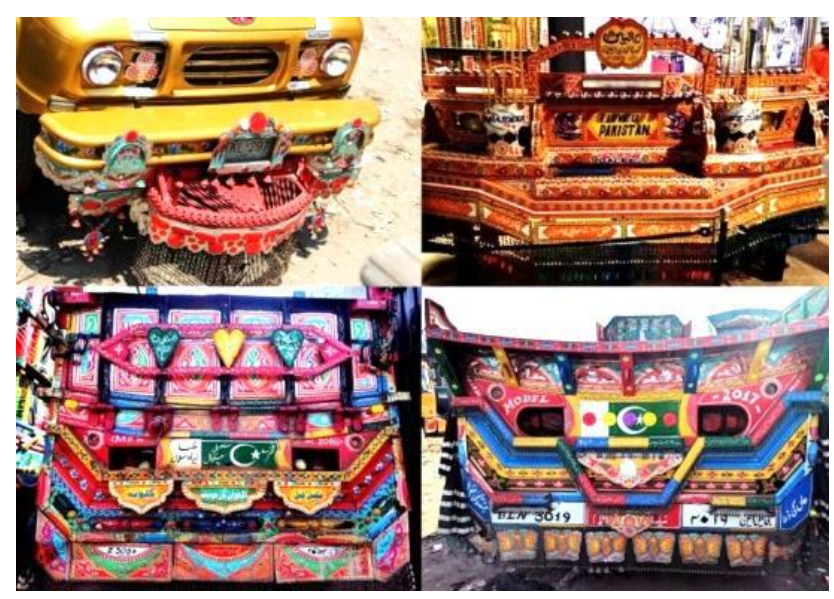

Plate.6 Dissimilar structural changes on frontal part of the trucks. 
Truck owners wish to spend maximum on their vehicles as they have a mindset that as much the vehicle will be decorated will bring more business because it will attract the customers. Some of the truck owners due to their love for the regional areas they belong get them adorned in their regional styles by adding traditional decorative accessories as well as provincial images. Intense decoration of vehicles shows the psyche of owners that how much he believe in decorating every minute space of the truck that is available in its structure. (Plate.7)

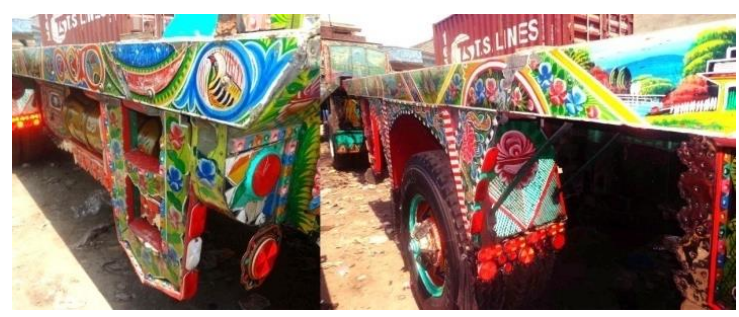

Plate.7 Attitude behind intense décor of vehicle.

Mirror work and chamak patiti ${ }^{[5]}$ (Plate.8) are frequently used in adornment. Chamak patiti is local term used for coloured sticking reflectors that are cut in a verity of designs and images to adorn these trucks. These reflectors shine in the dark of night when light of other vehicles fall on them. This decorative material makes truck shine in pitch dark and does not only beautify vehicles but also save them from unpleasant accidents. Special care is supplemented to the front and back of trucks where lavish Mirror work and chamak patiti makes trucks shimmer in the dark nights. When a driver purchases a truck he takes it to the workshop for additional structural design and ornamentation. In these workshops whatever decoration is done to the trucks by keeping in mind the taste and expenditures an owner can afford.

Chamak paṫii, include border designs, phūl patti $i^{[6]}$ design, birds, peacock, and fishes in a wider range of colours as red, green, orange, yellow, blues etc. craftsperson at the chamak patiti shop was Manzoor Hussain, who claimed his age to be forty years and is running his shop since he was just ten, described that chamak patiti work is a real hard work. Chamak patiti material is imported from Japan but locally made is also available. ${ }^{[7]}$

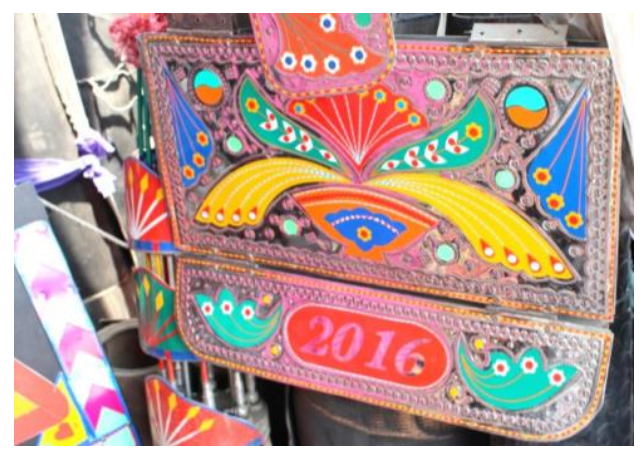

Plate. 8 Emboss metal work and chamak patti decoration.
Truck decoration and selected imagery in all means, is a question of ethnic identity and sometimes religious and cultural notions. The craftsmanship's in truck decoration involve steel work, which is dynamically used in the front and sides of trucks including zanjïr ${ }^{[8]}$ work and engravings with a combination of different floral and geometrical motifs.

Hanging chains on the front and back-fenders with different shapes like bell, hearts, pippal ${ }^{[9]}$ leaf or pān kā patt $\bar{a}^{[10]}$ attached with ghungrü $\bar{u}^{[11]}$, give off delightful jingling sound whenever vehicle hits furrows or ditches on road. Nazir Hussain is an expert in this field and working since sixteen years tells that this work is not only an element of embellishment but have its significant importance in decoration and otherwise. Jingling sounds of chains on rough roads works well on the psyche of truckers and helps them concentrate on driving more watchfully. He said, the sound of ghugrū and zanjīr keeps the driver active and awake during long routes of driving. ${ }^{[12]}$ (Plate.9)

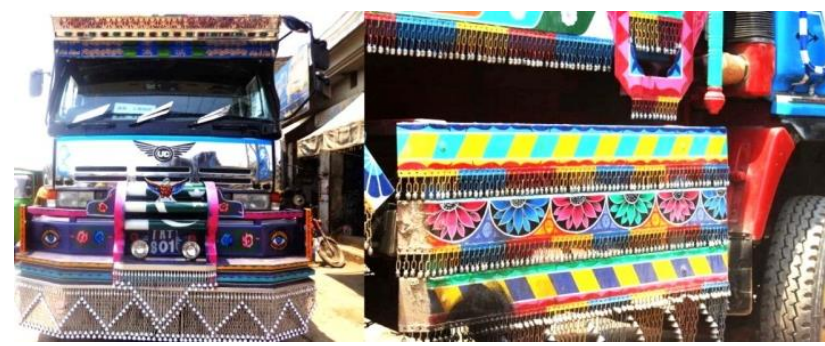

Plate.9 Metallic bells (ghungrū) and chain (zanjīr) work.

Interiors of trucks are also lavishly decorated. Plastic work involving appliqué patterns are done on seats. Patterns are cut with chapakkā ${ }^{[13]}$ cutter that stencils out drawn patterns. Different adhesives and nails are used to fix these designs. Elaborate mirror work is done to give it a look of Shish Mahal (palace of mirrors). Despite of coloured glass to give it an effect of mosaic acrylic is frequently used nowadays due to its easy availability and low cost. (Plate.10) Interior of trucks is sometimes extremely ornamental than exterior, weather affect decoration on exteriors but ornamentations last long in driver's cabin. Vibrant colours used in cabin create psychological effect on drivers' mood, bright colours give them happiness and energy and they feel relaxed in colourful environment.

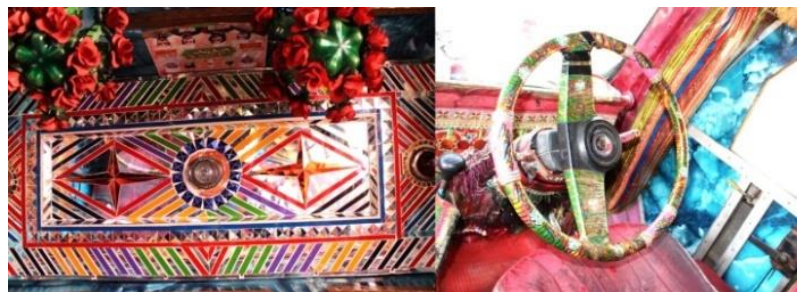

Plate.10 Highly decorative driver's cabin. 
Most distinct feature of unique truck art is the painter's approach toward painting with fearless mind, not caring about what others will or might think of the subject painted. Painting is one of the most important elements of truck ornamentation and caters to an infinite range of images. Ustād ${ }^{[14]}$ Hāji Akmal is master craftsperson from Lahore who is expert in painting on trucks. He told that different types of enamels are used for painting. Painters use air spray technique with the help of stencils and secondly simple brush technique is also applied. Paints that are used to paint are local cheap enamels in vibrant colours that are easily available on low rates. Paint work is cheaper than other craft works that are applied in ornamentation. (Plate.11)

About the selection of images Ustād Hāji Akmal told that the painter paints images sometimes according to his own choice but frequently by the choice of clients, taking influence from old paintings, photographic images from calendars or any other printed reference. He also said "I very often paint from photos the drivers bring to me, and designs they point out on other trucks, anything they want." [15] About art of painting he described two methods of painting.

1. Brush technique that includes images of bird, flowers, landscapes, portraits, animals and other native representations. Firstly the ground is painted white and then image is drawn on it and further details are added to visuals.

2. Spray technique is used to create different motifs and patterns that are cut as stencils and further paint is sprayed through them leaving image on the surface of truck.

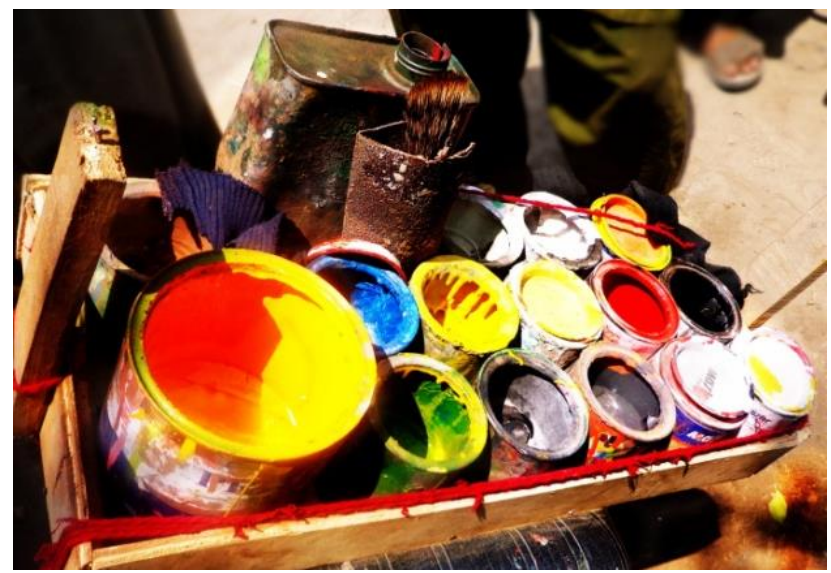

Plate.11 Enamels for painting on trucks-Painters Palette.

Images that are painted once get damaged due to weather effects and other reasons are repainted to keep it fresh and attractive. Masters working in this field transfer their skill in their shāgird ${ }^{[16]}$ who are either keen to learn this skill or do it as a source of income.

Truck decoration in Pakistan is a persistent practice in which practically all trucks are festooned with some amalgamation of epigraphic modus operandi, poetry, recurring patterns as well as figural metaphors. Both the metaphors and epigraphic formula may or may not be spiritual in nature. The beautification and assembling of trucks is done in a number of workshops. Front and rear of the trucks are bedecked in a different ways. Unlike the front of the trucks, features influential religious material whereas the rear of truck is fanciful predominantly has motifs from mythology and modern life. Decoration of a truck can indicate an immense arrangement of religious characteristics of individuals that are commonly coupled with a culture of truck decoration. Though, more explicitly, how changes in the content and nature of the decoration follow changes in the role of belief in Pakistani society.

Gul Shair, an owner of a truck decoration workshop, who has a good knowledge of traditional Pakistani truck decoration, describes the philosophy behind truck decoration. According to him, truckers don't even spend so much money on their own houses. He also said that he remember when drivers and owners of trucks say that they have put their whole life and livelihood in the decoration of their vehicles because these trucks for them are the source of income and if they do not decorate them they will consider themselves ungrateful to Allah for not respecting their vehicle with which they are earning their living. ${ }^{[17]}$

Truck art tells us broader reality about Pakistani society's unrelenting desire to intensify veracity. We have an enticing predisposition to ornament the whole lot, from ordinary cassette player to painted birds on trucks just because we are idealist and need to ignore monotony of life and through this exaggerate knowledge; perhaps we forget our monotonous lives.

\section{Impact of truck art, as popular culture on Pakistani society}

Popular culture is all about mass produced representations altering their appearance in any span of time appearing and disappearing or stylistically presented in photographs, though, present day popular culture is all about association, about seeing and observing things and about getting amused or distracted. [18] In Pop art, substance is visually standing apart from its known structure, secluded, and collective with dissimilar material. "The notion of pop art submits not as much to the art itself as to the approach that leads to it." [19] Transported, this word suggests a psychological change of condition or an imaginary movement from one state of mind to another but of course transported means moved swiftly or effortlessly from one place to another. ${ }^{[20]}$ Approach of transporting dissimilar images from popular culture invoked in truck decoration serves some cultural, social or political meanings and some trucks become itinerant patriotic billboards.

All those things that a man does and all those art that he creates for himself are known as Popular Culture. This Popular Culture provides him pleasure and diverts his 
mind and body from harsh realities that he faces in the daily business of life." [21] A popular secondary culture, though, sustained its conduit unobserved in the course of all the chronological periods of the region. So is truck art, a popular culture in Pakistan that gives a lot in the field of aesthetics and language.

Visuals depicted through truck art are not meant to be mere observation of nature; rather they tell us something about the philosophy of people who painted them. This philosophy applies when one studies the images and symbols painted on these vehicles. Truck bodies are perfectly painted by trained artists who paint them in workshops that can be found near truck stands all across the country, in Karachi famous point is Mauripur road and Hawks Bay, in Quetta Sariab Road is much known place, and in Lahore Badami Bagh and Pir Wadhai in Rawalpindi is popularly known areas with a number of workshops. Painted motifs and images on truck decoration can be categorized in nine groups:

1. Idealized elements of life, such as romantic villages, landscapes or beautiful women.

2. Elements from modern world, including pictures of political figures, patriotic images or poetic symbols.

3. Talismanic and fetish objects such as horns, eyes, fish and items of clothing.

4. Animals/birds (horses, peacock, deer etc).

5. Religious symbols and images as Burāq, tomb of the Holy Prophet pbuh and Khānā $K \bar{a}{ }^{c} b \bar{a}$.

6. Portraits of women or famous film stars.

7. Partial body parts in symbolic manner, like eyes, hands.

8. Geometrical shapes.

9. Botanical elements such as flowers, trees, roses etc.

All painted symbols and images are either copied from photos and magazines or transferred from generation to generation or handed down from ustād to shāgird who may be quite unaware of its meanings. Trained artists paint the entire truck with brightly coloured patterns, images and symbols along with some calligraphic expression. Nowadays lots of other images from popular culture, film stars, political figures and historical figures are painted on the back of the trucks. As a result truck art is not less than a fabrication of entertainment with elevated visibility. A range of metaphors that are painted on trucks challenge to ethnicity of fine arts by including metaphors from popular culture such as news, advertisements fashion trends etc.

An assortment of dissimilar imagery, from simple to complicated and from foreign to native these representations speak every story that many hearts felt. Elaborate foliage, birds, iconic representations, calligraphy, popular images, landscapes, love stories, silent messages, patriotic representations, so what is left that is not portrayed or transported to the minds of viewers through these moving canvases. From religious to politics, from entertainment to nostalgic, from poetic to logic these messages can be divided into categories that convey nostalgia, socio-political and religious notions, as well as moral and emotional idioms.

Decoration of $t \bar{a} j$ the highest part of trucks involves different craftsmanship and display holy images of Khānā $K \bar{a} b \bar{a}$, Masjid-i Nabvī and holy words like Allāh and Muhammad pbuh, Quränic Ayahs, words like māsh 'ā Allāh ${ }^{[22]}$, Subhāon Allāh ${ }^{[23]}$, Sufic ${ }^{[24]}$ images, as well as characters from Sufic allegories due to their sacred value in Islam. (Plate.12) Religious representations on trucks are a way to feel connected with Allah and express faith of truck owner. Some other religious interpretation can also be seen that express the faith of specific sect in Islam such as $Y \bar{a}^{c} A l i$ madad ${ }^{[25]}$ which shows Shiite faith of seeking help of 'Alī Ibn-i Abī Țālib ${ }^{[26]}$. Qurä’ nic Ayahs are direct manifestation of religion Islam and sufic poetic messages are other religious manifestations. All such manifestations take highest place in the structure of vehicle due to esteem and veneration.

Sacred images or religious are frequently used in popular culture to symbolize or reinforce assorted ideologies about complex beliefs of faith, purity, and morality in a religion. Very simple to highly complicated forms are used to convey religious notions, devotions or events. Devout metaphors directly affect the viewers and leave their impact on human psyche. Systems of metaphors or emblematic notions or direct images constitute certain order and determine the relationship with Holy. Such orientations in truck art help to know dissimilar belief system as well.

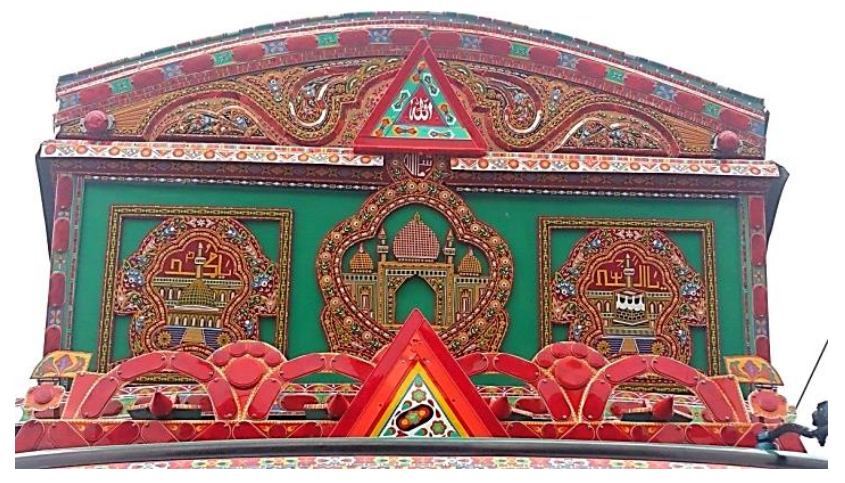

Plate.12 Sacred images of Khānā $K \bar{a}{ }^{c} b \bar{a}$, and Masjid-i Nabvī and other religious manifestations on the tāj of truck.

Depiction of a white horse with wings known as Burāq, represents the Prophet Muhammad's (pbuh) ride to the Heavens known as Mírāj ${ }^{[27]}$. Burāq is preferred symbol of trustworthy speed and commitment.

A winged horse exists in many traditions other than Islam, most well known being the Greek Pegasus. Generally some other winged creatures also exist in folklore all over the world: in Persia the Pari, Simurgh that carries $Z \bar{a} l$ to his nest at mount Elburz, in Hinduism Garuda, the flying bird that carries Krishna and Kālkī, one of the avatars of Krishnā rides on his victorious horse.

In historic Siyr-i Nabi of sixteenth century Ottoman period, the portrayal of the Burāq is with the face of a 
man, the body of a mule and the tail of a peacock. The Mírāj became particularly inspiring for the Șūfi orders and the image developed throughout the works of Persian poets including Farīd al-Din Atțār, Niẓāmī and Turkish poet Ghanizādé in whose work Burāq means lightening, changed into the legendary flying horse with a woman's face and frequently with a peacock tail. (Plate.13)

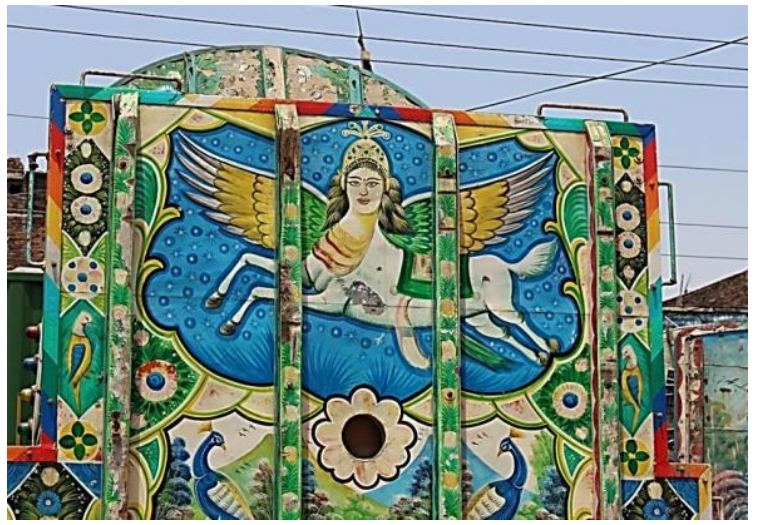

Plate.13 Indigenous Representation of Burāq on a truck's back panel.

National identity is not only a subject of determination and strategy but is entangled in the personified, material ways in which we live. [28] Other than religious arrangements, patriotic imagery has greater significance in truck art. National identity varies across time and space. In admiration for depiction of popular culture, patriotic representations appear in great intensity and familiarity. Iconic Pakistani flag is obligatory in truck adornment as it seems the décor will be incomplete without its presence either as an image or fixed in with any structure of vehicle. Along with Pakistani flag, China's flag is frequently seen that conveys message about PakChina friendship. Other than representations of flags of both countries on the rear panel of trucks portraits of army officials of both countries are also seen. Such representation show how patriotic Pakistani truckers are and how well aware they are of current affairs in between countries. (Plate.14) Besides such nationalistic delineation some other depictions are of political natures that are recurrently seen such as portraits of political and popular figures. Portrait of Benazir Bhutto and former Chief of Army Staff, General Raheel Sharif are the most favourite ones and are often seen on trucks in all areas of Pakistan. (Plate.15)

Portraits of other political figure such as Zia al-Haq, Zulfiqar Ali Bhutto, Chief of Army Staff General Qamar Bajwa are also painted to show the interest of truckers into politics and nationwide important issues or as if they are paying homage to their heroes. Other patriotic representations include battlefields, army emblems, and soldiers holding weapons are most much loved images that all show their love for country.

Other than patriotic depictions other pop images are also given much importance such as performing artists of television and theatre as well as celebrities from film world. It is not only that the images of Pakistani heroes and heroines that are preferred but owners of these trucks also desire to get portraits of their favourite Bolly wood actors and actresses, on their trucks. It seems as none of the contemporary subject is concealed from the eyes and mind of truckers. All these images are incessantly communicating in deviating ways through these moving canvases.

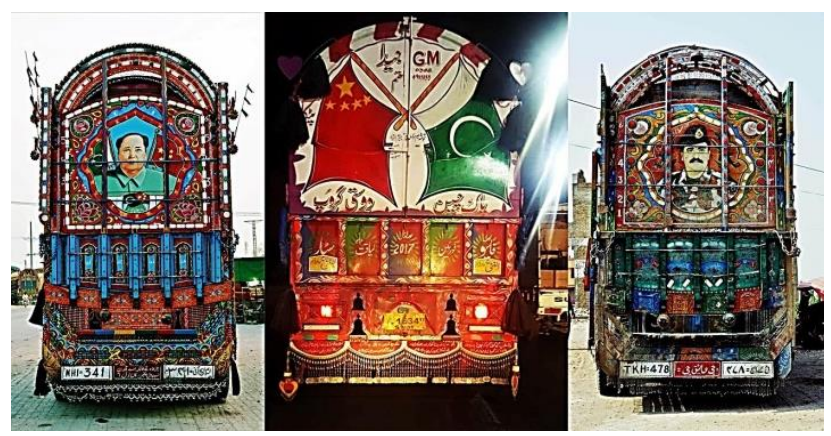

Plate.14 Nationalistic delineation on the rear panel paintings.

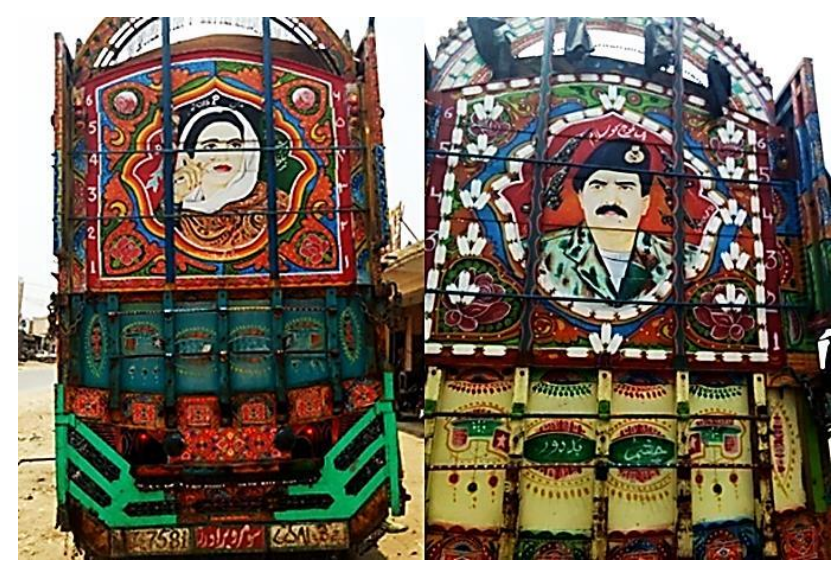

Plate.15 Portraits of Benazir Bhutto and former Chief of Army Staff, General Qamar Bajwa on rear panels of trucks.

Other than patriotic and political visual interpretations and religious and sufic presentations, some other metaphors are frequently seen on these trucks. Frequently we see that women's eyes are painted on the trucks. There are different interpretations of this image by the painters and drivers. A few out of many are that the eyes recall them the eyes of their beloveds. They cannot paint faces of their beloveds so they prefer painting only eyes.

Another very fact behind the depiction of this image is the philosophy of evil eye. In many culture it is believed that evil eye cause some injury or bad luck for someone who is not been liked due to envy or disliking. This shows a power of a person who can inflict bad luck or injury to someone due to his evil eye on him. In Arabic evil eye is called 'Ain al-Hasad and concept of evil eye prevails in many cultures and seek protective measures against it. 
For remedy of evil eye in Islam șadqāh $h^{[29]}$ is recommended and some tradition practices are also suggested such as tying black cloth with vehicles fixing horse shoe and reciting or writing Māsh 'a Allāh. Tradition of tying black cloth with vehicles, fixing horse show and writing Māsh 'a Allāh on tāj of trucks is a common practice. (Plate.16)

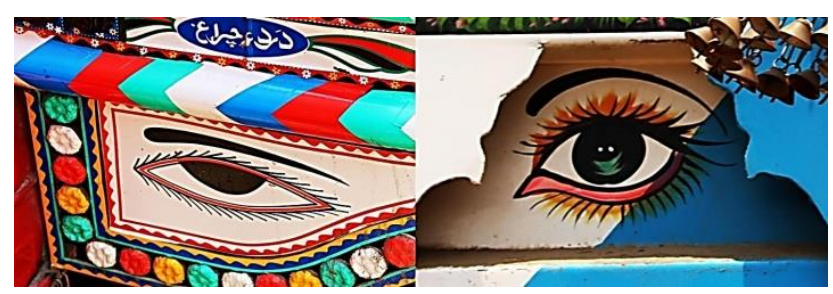

Plate.16 Frequently painted symbol of eye.

Ghulam Muhammad a truck driver said, "When we go on driving long routes of months and months, these eyes recall us eyes of our family member who keep on waiting for us when we are away and they pray for our return." [30]

Other popular metaphors include floral plants and birds prominently Roses, eagles, sparrows and peacock are frequently painted. (Plate.17) Birds in vegetation composition are seen both in painting and sometimes made in metal like relief and further painted or embellished with decorative materials. Peacock is a symbol of Paradise, rebirth and immortality of soul. In Farīd al-Din Atțār's Manțiq al-Țāir, where the metaphor of unfathomable divine is Great Ocean, thirty birds start their journey to reach Simurgh.

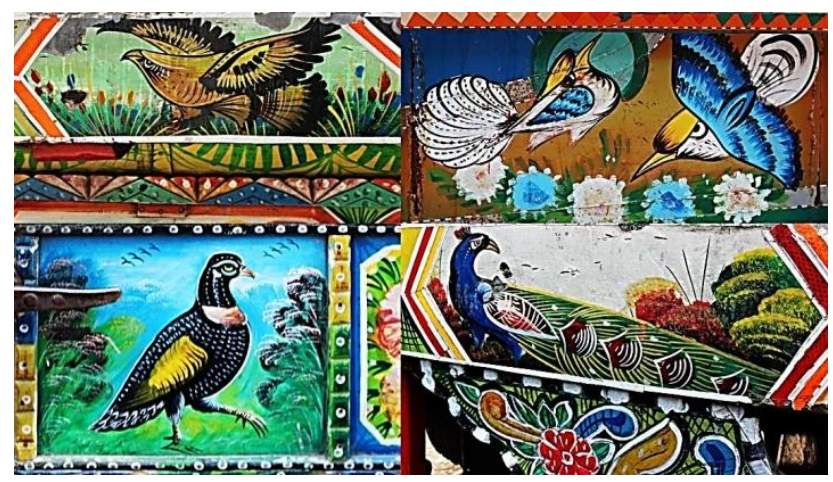

Plate.17 Peacocks, sparrows, eagle in natural habitat.

Other subjects are also seen on vehicles such as Mughal miniature paintings appear in crude and brash expression. Lots of sceneries are also depicted by the painters, such as serene landscapes that are painted in regional as well as foreigner styles showing hillocks, vegetation, winding roads, shining sky, mountains, water lakes, birds animal all. One can enjoy a never ending fantasy of the painters through genre of landscape. (Plate.18) Some of the more well-liked countryside scenes show the hunt, deer, lions, , hunting lodges or mountains cottages, which show inspiration taken from Mughal miniatures. The striking, hodgepodge of images is an imaginative amalgamation with identical enjoyment, where we can enjoy fusion of east and west, worldly and consecrated are painted with masterly skills of painters.

A metaphoric narration that suggests us to come out of trap of dogmas, and do not remain deprive of a journey in search of truth. Representation of birds on trucks evoke same message where we find birds in quest of some journey. None of the bird is ever painted static, rather always in motion surrounded by some vegetation or flying high in sky. Bird's depictions demonstrate their journey they may have started together but their destination is different from each others. Curves are so lyrical in drawings and colours bright and lively. Every representation seems metaphoric in its nature like falcon and eagles as symbol of ambition and power, and the fiery animals represent strength.

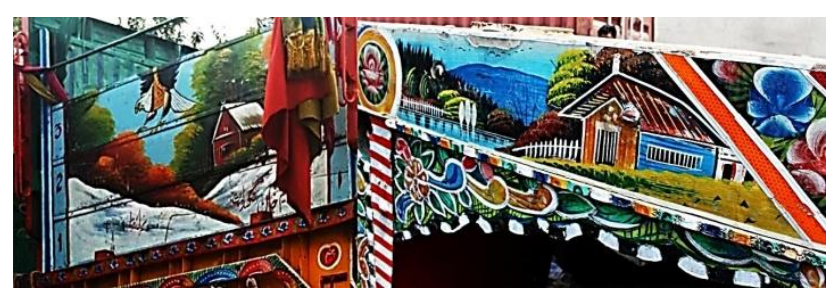

Plate.18 Semi regional and foreign representation of landscape painted on trucks.

In a culture full of poets and scholars who offer a lot to express through words give an insight to painters to communicate through writings on vehicles. The most interesting part of truck decoration is epigraphy that involves different poetic sentences and the name of the owner or some proverb in native style and language. Not renowned but unknown poets who get commissions to write poetic inscriptions for the owners of trucks in their regional language.

In truck decoration epigraphy is used as per arranged spaces in the compositions of different parts of vehicle. From romantic to poetic, from humorous to nostalgic or sometimes desperate and sometimes Qur ānic verses with addition of the owner's or company's name all are engaged as a mandatory part of truck decor. Qur'ānic messages like Māsh' ā Allāh, Bismillāh are set on higher areas such as tāj or upper edge of wind shields. Invocation to Muslim saints can also be witnessed on higher spaces though; humorous sayings are painted on any part of trucks and draw the attention of other drivers or passerby's. Epigraphy messages express diverse moods. Some frequently seen epigraphic messages are; Jalnay wālay kā mū kālā ${ }^{[31]}$, Hāran do rāstā lo ${ }^{[32]}$, Māṇ ki du'ā jannat ki havā ${ }^{[33]}$ (Plate.19), Daikh magar piyār say [34] Pasand sajnān di $i^{[35]}$ and $\underline{\text { Chashm-i bad } d u ̄ r}{ }^{[36]}$ (Plate.22). 


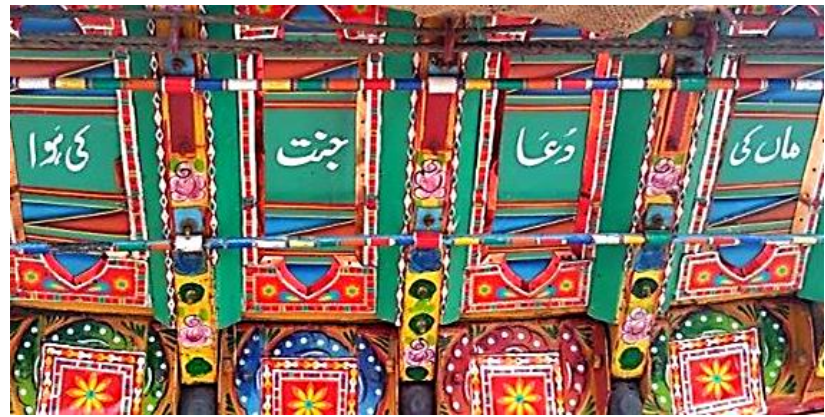

Plate.19 Māṇ ki dư ā jannat ki havāa

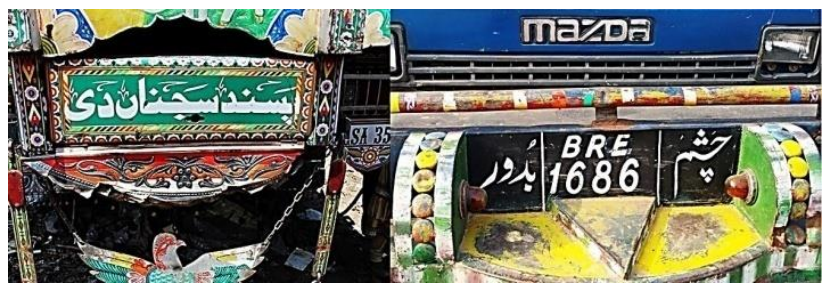

Plate.20 Pasand sajnāṇ di (left) and Chashm-i bad dūr (right).

Epigraphy's compositional sense sometimes creates irrelevant or humorous sentences, such as;

Touch Hāji Miyāṇ Munīr Aḥmad Me nașīb apnā apnā Not. Which has no relevance if read as one sentence but a creative composition mixing English and Urdu idioms is so exciting, mainly it addresses to Touch Me Not a slang (do not touch me) and Hāji Miyān Munir Ahmad is the name of truck owner and another epigraphic message nașib apnā apnā is a suggestion about one's destiny. Epigraphic sections are like calligraphic board displaying messages for public or serve as a form of communication with audience. Communication is a source of sharing hearts and ideas and all epigraphic messages convey what a driver or owner of vehicle wants to convey to onlookers. Whether message is to the point or sophisticated, sombre or entertaining, communication is done transversely to another in a way that is comprehensible, indistinct or imprecise. Epigraphy on trucks sometimes used for advertising the name of owner or companies as well, beautifully composed in floral or abstract designs names of owners increase the reputation and business for them. These moving canvases on roads, persistently humming, with messages, whether one realize it or not. Though, artists and artisans involved in this special art are not trained from art schools or academies yet they perform their job incredibly and truck art plays a significant role to communicate values, beliefs, and practices.

\section{Conclusion}

In modern era, popular culture is more or less without any definition. Its significant appearance is seen in truck art of Pakistan. From earlier mass media what sets apart contemporary popular culture is that it offers means of entertainment and pleasure that is enjoyed by a massive amount of people. Truck art as popular culture is not only about market oriented activities intended to bring in business to raise income, rather it also serves as a strong mean of communication between communities. What cannot be said is said, what cannot be expressed is expressed through truck art and pleasantly faiths, beliefs, values, traditions, narratives all are transferred. From very simple to complicated, from very crude to polite, messages are delivered to society. Issues are challenged, taboos are addressed, and mores are transferred in a very entertaining way.

Brightly moving emblematic illustrative canvases on roads communicate what sometime intellectual platforms cannot. What a strong denote of communication these vehicles are, purring with images continuously on crowded roads. There vivacity, shocking and surprising images, calligraphic communications all prove it an extraordinary art that is strong and influential in its essence. Language of signs and symbols, direct narratives subjugated by meticulous ethic of proudly independent craftsmen all virtually demonstrate its uniqueness. These moving canvases do not only hold animated metaphors, nonetheless they are equally pragmatic, conceptual, representational terminologies and connotation and powerful means of communiqué for people.

\section{Acknowledgement}

I have been fortunate to thank Ramsha Khalid and Anum Malik, MPhil Scholars from College of Art and Design, University of the Punjab, for their contribution of photography in this paper and I am also thankful to Ahmed Faraz, Assistant Professor, Sargodha University who helped in composing photographic images as I desired. This research would not have been possible without their generous help.

\section{References}

${ }^{1}$ Berys Gaut and Dominic Mclver Lopes, eds. High Art vs. Low Art, in Routledge Companion to Aesthetics, $2^{\text {nd }}$ ed. (London: Routledge, 2005), 527-540.

${ }^{2}$ Ustād, is an Urdu word means 'teacher'.

${ }^{3} T \bar{a} j$ is an Urdu word that means crown. Crown is always most appealing part of the trucks.

${ }^{4}$ Partal, Himalayan Spruce (Picea smithiana) is locally available in Northern area of Pakistan.

${ }^{5}$ Chamak patti, coloured plastic reflectors.

${ }^{6}$ Phūl patti, means flower with leaves.

7 Manzoor Hussain, Interviewed by author, Lahore, Pakistan. May 4, 2018.

${ }^{8}$ Zanjïr, an Urdu word meaning chain

${ }^{9}$ Pipal, Ficusreligiosa or sacred fig.

${ }^{10}$ Pān kā pattā, betel leaf.

${ }^{11}$ Ghungrū, small metallic bells that are strung together and tied to the feet of classical Indian dancers.

12 Nazir Hussain, Interviewed by author, Lahore, Pakistan. May 2, 2018. 
${ }^{13}$ Chapakkā, vertically set saw that stencil out shapes from patterns.

${ }^{14}$ Ustād is an Urdu word meaning teacher or master who teaches certain skill.

${ }^{15}$ Ustād Hāji Akmal, Interviewed by author, Lahore, Pakistan. May 3, 2018.

${ }^{16}$ Shāgird is an Urdu word that means student more specifically trainee of some craft guild.

${ }^{17}$ Gul Shair, interviewed by author, Lahore, Pakistan, May 15, 2018.

${ }^{18}$ Raymond F. Betts, A History of Popular Culture: More of Everything, Faster, and Brighter (New York: Routledge, 2004), 9.

${ }^{19}$ De la Croix, H. and R. Tansey, Gardner's Art through the Ages, (New York: Harcourt Brace Jovanovich, 1980), 94.

20 Raymond F. Betts, A History of Popular Culture: More of Everything, Faster, and Brighter (New York: Routledge, 2004), 9.

21 Tom Pendergast and Sara Pendergast, eds. St. James Encyclopedia of Popular Culture, vol 4 (America: Thomson, 1999), 5.

${ }^{22} M \bar{a} \underline{s h} \bar{a}$ Allāh, an Arabic phrase that means 'as God willing' or 'God has willed', expresses admiration, delight, tribute to, or gratitude for an event or person.

${ }^{23}$ Subhān Allāh, Arabic phrase that means 'Glory be to Allah'.

${ }^{24}$ Sufic, Islamic religious group who lives simple life and are focused to prayers and meditation.

${ }^{25} Y \bar{a} \quad$ 'Ali madad, is renowned Shî̃ā Muslim prayer 'Ya Ali Madad' means, 'O Ali, help us'. It is also a traditional Ismaili greeting.

26 'Alī Ibn-i Abī Ṭālib, cousin of Prophet Muhammad pbuh and Shiite consider Him successor of Prophet Muhammad pbuh.

27 Mírāj, is an Islamic prodigy of the ascension of the Prophet Muhammad pbuh into heaven. In this prodigy, Muhammad is arranged for his meeting with God by Jibrāīl and Mīkāīl while he was sleeping one evening.

${ }^{28}$ Raymond F. Betts, A History of Popular Culture: More of Everything, Faster, and Brighter, (New York: Routledge, 2004), vii.
${ }^{29} S a d q \bar{a} h$, is an Arabic word that means charitable contribution, whose amount is at the will of the benefactor.

${ }^{30}$ Ghulam Muhammad, Interviewed by author, Lahore, Pakistan. May 29, 2018.

${ }^{31}$ Jalnay wālay $k \bar{a}$ mū $k \bar{a} l a \bar{a}$, in Urdu, means 'one who feels jealous will turn black faced'.

${ }^{32}$ Hāran do rāstā lo, in Urdu, means 'horn, and take way'.

${ }^{33}$ Mān ki du ' $\bar{a}$ janat ki havā, in Urdu, means 'prayer of mother is like breeze from Heaven'.

${ }^{34}$ Daikh magar piyār say, in Urdu, means 'look at me with love'.

${ }^{35}$ Pasand sajnān di, in Punjabi, means 'as per beloved's choice'.

${ }^{36}$ Chashm-i bad dūr, in Urdu, means 'stay safe from evil eye'.

\section{Bibliography}

Aziz, K.K. The meaning of Islamic art. Lahore: Al-Faisal, 2004.

Becker, Udo. The Continuum Encylopedia of Symbols. London: The Continuum International, 2000.

Canby, Sheila. R. The golden age of Persian art. London: British Museum press, 1991.

Caspari, Elizabeth and Ken Robbins. Animal Life in Nature, Myth and Dreams. Wilmette Illinois: Chiron, 2003.

Croix, De la and R. H. Tansey. Gardner's Art through the Ages. New York: Harcourt Brace Jovanovich, Inc., 1980.

Elias, Jamal J. On Wings of Diesel-Trucks, Identity and culture in Pakistan. England: One World, 2011.

Gaut, Berys and Dominic Mclver Lopes, eds. High Art vs Low Art, in Routledge Companion to Aesthetics, $2^{\text {nd }}$ ed. London: Routledge, 2005.

Martin, Kathleen. The book of symbols, reflections on archetypal images. London: Taschen, 2010.

Open, Renata Von. Art on Wheels. Pakistan: Ferozsons, 1992.

Pendergast, Tom and Sara Pendergast. Eds. St. James Encyclopedia of Popular Culture, vo.l 4. America: Thomson, 1999.

Betts, Raymond F. A History of Popular Culture: More of Everything, Faster, and Brighter. New York: Routledge, 2004. 